\title{
Research Based on International Trade System and the Pursuit of Free Digital Trade
}

\author{
Houqi Ji \\ Business School, City University of Macau, Macau 999078, China \\ Email: 1095851179@qq.com
}

\begin{abstract}
The world is witnessing the digitization of the production, exchange and consumption of goods and services in economy. The Internet and cross-border based data flows are becoming important trade channels as more products are traded online or with integrated functions that are based on digital connections. We emphasize the technical emergency element in existing international rules, which shows that technological change is a driving force for competitive regime creation and forum transformation, contributing to the process of fragmentation of the international trading system.
\end{abstract}

Keywords: international trade, free digit, global economy, digitization

\section{Introduction}

Differences in Internet governance have expanded over the past decade with an increasing number of countries eager to use Internet and data policies to achieve economic and trade goals, reflecting the autonomy that countries must have in formulating such policies ${ }^{[1]}$. These dynamics are exerting an important impact on the international trading system by imposing challenges on trade rules and creating demands for new ones. This has led to a growing debate in the trade world about digital trade. States led by the United States have pushed for rules as a way to constrain national Internet policy and support trade in digital goods and services. Digitization is driving profound changes in the production, exchange and consumption of goods and services, including changes in traditional industries as well as the emergence of new products and services based on digital technology. Digital trade emerged as a concept that captured many of the trade flows in which the Internet played a central role. The definition of digital trade is usually quite broad, which includes the digital trade in goods or services, digital or physical delivery. This broad definition encompasses a number of digitally driven processes, including e-commerce, in which transactions and activities such as search, payments, and logistics are handled by digital platforms. It also includes trade in goods and services that are shifting from physical to digital forms in areas such as entertainment, publishing, software, music and financial services. It also includes new areas of economic activity, such as cloud computing and the application economy.

In recent years, all of these components of digital trade have undergone rapid growth, as a result, digital trade is becoming an important mechanism for conducting trade ${ }^{[2]}$, as a result, a growing number of products, such as cars, home appliances and industrial machinery, are integrated with digital technology. As a result, data is becoming the basis of traditional merchandise trade, which will be a trend that is expected to increase significantly with the development of technologies such as autonomous driving and the Internet of Things (IoT). The growing importance of digital trade has important implications for the international trading system. As goods shifted from physical to digital, there is debate about the rules of trade. Similarly, states are debating the meaning of market access commitments as more services are made available online. Products delivered in a digital manner and the goods embedded with digital services posed challenges of the basic concepts of how the international system works, such as the distinction between goods and services and the patterns of supply that form the core elements of agreements such as the General Agreement on Tariffs and Services (GATS). In addition, digitization made it possible the use of new policies that have an impact on international trade ${ }^{[3]}$. For example, policies that block access to websites and regulate the flow of data across borders could have a serious impact on trade. While goods (as vehicles, industrial machinery) are subject to relatively clear and predictable trade rules. However, the data they generate and rely on are not subject to these rules, which allows the use of data policies to influence trade in such goods. The rest of this article is organized as follows. The second section introduces the key concepts and development status of digital trade and international trade system. Section 3 discusses the differences in governance of Internet countries as key drivers of the digital trade agenda. Section iv examines the political economy of the digital trade agenda within the international trading system. Section V discusses the results of this analysis. 


\section{Key concepts and status quo in the international trading system and free digital trade}

\subsection{Key concepts}

Over the past few decades, the multilateral trading system has undergone major changes. In addition to more countries joining the multilateral system, the scope of the system has also changed significantly to include issues such as investment, services and intellectual property rights. Parallel changes have taken place at the bilateral and regional levels. Through these processes, the international trading system has shifted from a shallow definition of trade that focused only on border issues such as tariffs and quotas to a deeper system that governs a growing number of issues behind the border. Some newer issue areas, such as intellectual property, have been incorporated into the trade regime, previously governed through non-binding or poorly enforced global governance mechanisms, and have been introduced into the international trading regime through a process of institutional and forum transformation.

The driving forces behind the push for deeper integration are complex. Trade literature gave more emphasis on the role of interest groups and efforts, which were taken as a factor in the development of trade policy. As key to advancing the post-war international trading system, this paper gives special focuses on explanation of the role of political mobilization of interest groups in shaping U. S. trade policy. From this perspective, one motivation for international trade policy is to focus on specific rules that are hard to change by subsequent governments. As the EU becomes an important bloc within the international trading system, other studies have highlighted the mobilizing role of interest groups in shaping European trade policy and in building transnational business alliances.

\subsection{Status quo in development}

In recent years, new policies in international trade have led to an active movement around digital trade. The first is to integrate Internet governance into the international trading system, and the second is to push for stricter digital trade rules within the international trading system. The US has emerged as the main initiator of the integration of digital issues into the international trading system, and the globalized US at a fast pace in technology industry is demanding a more favorable and predictable global competitive environment. The resulting US-led digital trade agenda has been promoted at the multilateral level of the WTO, as well as in regional and bilateral forums. 21st Century trade agreements, particularly the Trans-Pacific Partnership (TPP) and the Transatlantic Trade and Investment Partnership (TTIP), are seen by U. S. trade policymakers as important steps toward new digital trade rules. The TPP has been described by US trade policymakers as the most ambitious and visionary Internet trade agreement ever (USTR 2015).

With the growth of literature on technology and policy within international institutions, there is an awareness that digital trade is becoming an important issue. However, those who explore the politics of international trade have paid limited attention to the research on the digital trade agenda. This paper is conducted with aims to address this gap by analyzing the roots of the digital trade agenda and the politics of negotiation around it in different forums. The goal of the digital trade agenda is not made just to update the international system to better align digital trade with deeper trade liberalization by overcoming existing barriers to trade in goods and services and making more products digital. We highlight technological resilience in international trade rules and how technological change undermines the effectiveness of existing rules and drives institution creation and forum transformation.

\section{Differentiation of national Governance mechanisms for the Internet}

Over the past two decades, the debate on Internet governance has been conducted through a range of different venues and institutions. While organizations such as the International Telecommunication Union (ITU) and INTELSAT have played a role in regulating broadcasting and telecommunications in the past, the advent of the Internet has changed the regulatory landscape ${ }^{[4]}$. In general, Internet governance is characterized by a diversity of institutions, with no clear single focus institution or set of institutions with a clear mandate. In 2011, the World Summit on the Information Society (WSIS) defined Internet governance as the role of government, the private sector and civil society in formulating and applying common principles, norms, rules, decision-making processes and programs that influence the development and use of the Internet.

Scholars in the field of Internet governance argue that we need to think of Internet governance as a multi-level structure. These different dimensions move from the technical dimension of Internet governance to the dimension at which economic and social interactions take place, although there are questions about the ability of more technology-oriented governance forums to manage the economic and social dimensions of the Internet. Due to the lack of an overall coherent direction for Internet governance, the Internet Governance Forum has yet to explore the impact of digital trade. Issues related to digital 
trade are occasionally discussed, but there is no consistent resolution or direction. Countries have huge policy space on Internet governance, and increasingly diverging views on the rules governing the digital space, including strategies with important trade and economic objectives.

\section{Integration of digital trade into the international trading system}

The leading digital companies have made a political push to integrate key elements of digital trade into the international trading system. This trend then extended to non-digital companies, particularly service companies that see digitalization as a better route to market access for their services. While this effort includes activities in different parts of the world, the main impetus is coming from the United States, reflecting the fact that most of the leading digital companies are from America, as well as the strong power on the international trade. To analyze and discuss the growth of digital interest groups in the United States and then discuss some of the key efforts to integrate digital trade into the international trading system.

In the early days, many Internet companies held that their relationship with government is different from that of a typical business. But with the development of these companies domestically and globally, they have addressed policy issues in ways similar to other sectors of the economy. Over the past decade, digital companies have become important political forces in Washington DC through massive efforts in lobbying and campaign. The issues on which digital companies lobby have evolved over time. Early on, they focused on domestic issues such as intellectual property and domestic e-commerce. However, an analysis of lobbying information submitted by the companies shows that they are increasingly active in lobbying on international trade issues, including international trade agreements. Digital trade has become an increasingly important part of global trade. More and more goods and services are exchanged over the Internet, and more and more products are connected and data oriented. The rapid spread of digital technologies in a growing number of economic sectors has had an important impact on the international trading system. Changes brought about by digitization are challenging existing trade rules and demanding new ones.

\section{Conclusion}

The campaign to integrate digital trade into the WTO shows the challenges of technological change being addressed through existing institutions. As can be seen from the debate over the definition of technological neutrality or electronic transmission, there are no clear rules on how to deal with this technological shift. In addition to questions of technical capacity and mandate, the political and institutional design of existing institutions may make it difficult to address these new problems. In today's world, digitalization and technological change are important factors in the creation of competition systems, the transformation of forums and the fragmentation of international trading systems.

\section{References}

[1] Zhang Bin. Import commitments in international Trade Agreements: History and present situation[J]. International Economics And Trade Research, 2020, 36(06):101-112.

[2] Zhang Tingting, Li Zheng. International trade development and the construction of a new system of higher level open economy[J]. Henan Social Sciences, 2020, 28(02):47-56.

[3] Liang Yong. Security Exception Rebalancing in International Trade System[J]. Law of China, 2020(02):142-155.

[4] Liu Jia. Discussion on the New scheme of international trade under the background of building the new system framework of open economy[J]. Taxes, 2019, 13 (33) : 220. 